\title{
PENGGUNAAN E-MONEY TERHADAP PERILAKU KONSUMTIF MAHASISWA YANG DIMEDIASI KONTROL DIRI
}

\author{
Luh Gede Kusuma Dewi \\ Kusumadewi5758@gmail.com \\ Nyoman Trisna Herawati \\ I Made Pradana Adiputra \\ Fakultas Ekonomi Universitas Pendidikan Ganesha
}

\begin{abstract}
This study analyzes the effect of e-money on the consumptive behavior of undergraduate accounting students in Bali Province which is mediated by self-control. This study uses a quantitative research design with an ex post facto approach and path analysis techniques. Data was collected through distributing questionnaires with digital form media to all universities in Bali. Population was S1 accounting students in all universities in Bali Province, while the sample was selected using purposive random sampling technique. The total sample of the study was 354 people. The results of this study show the following results. First, the use of e-money has a significant direct effect on consumptive behavior. This indicates that students improve self-control in countering the use of e-money, so that e-money can function as expected, which is able to facilitate student transactions, and avoid the downside. Second, with self-control, students as e-money users can also avoid consumptive attitudes. Third, self-control is able to mediate between e-money and consumptive behavior, so if students have high self-control, the use of emoney can suppress or reduce consumptive behavior in students. In that sense, students use e-money only as much as they need, for example for tuition payments or buying other primary needs.
\end{abstract}

Key words: e-money; consumptive; self control; university student.

\begin{abstract}
ABSTRAK
Penelitian ini menganalisis pengaruh e-money terhadap perilaku konsumtif mahasiswa S1 Akuntansi di Provinsi Bali yang dimediasi oleh kontrol diri, Penelitian ini menggunakan desain penelitian kuantitatif dengan pendekatan ex post facto dan teknik analisis jalur. Data penelitian ini dikumpulkan melalui penyebaran kuesioner dengan media formulir digital ke seluruh Universitas yang ada di Bali. Populasi penelitian adalah mahasiswa S1 Akuntansi yang ada di seluruh Universitas di Provinsi Bali, sedangkan sampel dipilih dengan menggunakan teknik purposive random sampling. Total sampel penelitian berjumlah 354 orang. Hasil penelitian ini menunjukkan hasil sebagai berikut. Pertama, penggunaan e-money berpengaruh langsung secara signifikan terhadap perilaku konsumtif. Hal ini mengindikasikan agar para mahasiswa meningkatkan kontrol diri dalam mengimbangi penggunaan emoney, sehingga e-money bisa berfungsi sesuai dengan yang diharapkan, yaitu mampu mempermudah transaksi mahasiswa, dan menghindari sisi buruknya. Kedua, dengan adanya kontrol diri, mahasiswa sebagai pengguna e-money juga dapat terhindar dari sikap konsumtif. Ketiga, kontrol diri mampu memediasi antara e-money dengan perilaku konsumtif dengan demikian jika mahasiswa memiliki kontrol diri yang tinggi, maka penggunaan e-money dapat menekan atau mengurangi perilaku konsumtif pada mahasiswa. Dalam artian, mahasiswa menggunakan e-money hanya sebatas kebutuhan saja, misalkan untuk pembayaran kuliah atau membeli kebutuhan primer lainnya.
\end{abstract}

Kata kunci: e-money; konsumtif; kontrol diri; mahasiswa.

\section{PENDAHULUAN}

Indonesia merupakan salah satu negara dengan pertumbuhan teknologi digital yang pesat di kawasan Asia Tenggara. Kemajuan teknologi digital di Indonesia menggiring perkembangan di berbagai aspek kehidupan, seperti adanya sekolah atau kursus online, ojek online, bioskop online, hingga 
dalam sektor kegiatan ekonomi yang sebelumnya berjalan secara konvensional mulai bergeser ke arah digitalisasi. Sebut saja dalam kegiatan jual beli barang ataupun jasa. Jika dahulu pembeli dan penjual harus bertemu di suatu tempat yang bernama 'pasar. Kini pasar telah hadir dalam wujud digital, yang disebut $e$-commerce yang ada di genggaman tangan siapapun melalui gawai digital. "Online shopping", begitu para kaum milenial menyebutnya. Perkembangan transaksi digital tidak berhenti sampai disitu. Sumanjeet (2009) menyebutkan bahwa sistem pembayaran digital muncul sejak hadirnya e-commerce ini. Pembayaran dalam transaksi digital disebut e-payment, dengan uang digital yang disebut e-money, dan dompet digital yang disebut $e$-wallet. Digital payment adalah teknologi yang memberikan pandangan mengenai pembayaran nontunai yang lebih praktis, efisien serta aman dalam bertransaksi melalui media digital (Puspita, 2019)

Munculnya e-money di Indonesia, telah diregulasi oleh pihak yang berwenang, yang dalam hal ini adalah Bank Indonesia. Menurut Sihombing (2017) Peraturan No. 11/12/PBI/2009 tentang uang elektronik (emoney) yang dikeluarkan oleh Bank Indonesia menyebutkan bahwa uang elektronik adalah alat pembayaran yang memenuhi unsur-unsur sebagai berikut: diterbitkan atas dasar nilai uang yang disetor terlebih dahulu oleh pemegang kepada penerbit, nilai uang disimpan secara elektronik dalam suatu media seperti server atau chip, digunakan sebagai alat pembayaran kepada pedagang yang bukan merupakan penerbit uang elektronik tersebut, dan nilai uang elektronik yang disetor oleh pemegang dan dikelola oleh penerbit bukan merupakan simpanan sebagaimana dimaksud dalam undang-undang yang mengatur mengenai perbankan.

Inovasi digitalisasi bentuk uang ini memberikan dampak positif dan negatif terhadap masyarakat sebagai pengguna $e$ money. Kasus-kasus penipuan yang mengatasnamakan penyedia e-money tertentupun tidak dapat dihindarkan. Akan tetapi keuntungan yang dirasa oleh pengguna $e$ money mampu membuat pertumbuhan $e$ money semakin meningkat baik dari sisi penyedia maupun dari sisi penggunaannya. Jika dilihat dari sisi positif penggunaan e-money, terdapat berbagai keuntungan yang dapat dirasakan oleh pengguna $e$ money, antara lain sebagai berikut. (1) merchant tidak perlu menyiapkan uang pecahan kecil untuk uang kembalian. (2) pengguna tidak perlu membawa banyak uang cash saat berbelanja. (3) pembayaran untuk belanja online semakin mudah dilakukan kapanpun dimanapun (Ramadhan et al., 2016). Selain itu, melimpahnya promo dan diskon yang diberikan oleh pengembang emoney seperti Gopay, Ovo, Dana, shopeepay, iSaku, dan lain sebagainya menjadi salah satu daya tarik e-money yang tidak dapat diabaikan. Seorang pengguna e-money bisa memiliki berbagai macam layanan demi mendapatkan manfaat berbagai macam promosi dan diskon yang ditawarkan oleh para penyedia $e$-money.

Potensi pembayaran dengan e-money di kawasan asia tenggara diramalkan akan mencapai 1 Triliun dolar pada tahun 2025 nanti (Ramli, 2020). Data dari Bank Indonesia menunjukkan total transaksi dompet digital Indonesia semester pertama di tahun 2019 adalah sejumlah 56,1 Triliun Rupiah dengan rincian sebaran pangsa pasar pengguna masing-masing e-money adalah sebagai berikut Tabel 1.

Dari Tabel 1 dapat diketahui bahwa produk e-money Ovo yang disediakan oleh Grab mendominasi pangsa pasar e-money di Indonesia pada tahun 2019 dengan total sebaran pasar sejumlah $37 \%$ pengguna dan total transaksi sejumlah 20,8 Triliun Rupiah. Disusul oleh produk e-money Gopay yang merupakan e-money dari perusahaan Gojek yang merupaka perusahaan dengan nilai valuasi perusahaan lebih dari 10 Miliar dolar (Decacorn) pertama di Indonesia. Pangsa pasar e-money Gopay di Indonesia pada tahun 2019 dengan total sebaran pasar sejumlah $17 \%$ pengguna dan total transaksi 
sejumlah 9,5 Triliun Rupiah. Aplikasi emoney Dana menempati posisi ketiga dengan sebaran pasar sejumlah $10 \%$ dan total transaksi 5,6 Triliun Rupiah. Dan pada posisi keempat diduduki oleh produk e-money LinkAja yang merupakan penyedia e-money dari Badan Usaha Milik Negara, dengan sebaran pangsa pasar sejumlah 3\% dan total transaksi yang mencapai 1,6 Triliun Rupiah. Total 56,1 Triliun Rupiah transaksi e-money di tahun 2019 membuktikan minat tinggi masyarakat dalam menggunakan e-money sebagai media transaksi keuangannya.

Tabel 1

Data Transaksi dan Pangsa Pasar e-money

\begin{tabular}{ccc}
\hline Nama $e$-money & Total transaksi (Rupiah) & Pangsa pasar \\
\hline OVO & 20,8 Triliun & $37 \%$ \\
Gopay & 9,5 Triliun & $17 \%$ \\
Dana & 5,6 Triliun & $10 \%$ \\
LinkAja & 1,6 Triliun & $3 \%$ \\
\hline
\end{tabular}

Sumber: data diolah

Diluar dari beragam kemudahan dan manfaat dalam menggunakan e-money, juga terdapat kekurangan atau sisi negatifnya. Salah satu sisi negatif yang muncul di karenakan kemudahan dan kepraktisan dalam menggunakan e-money adalah pemborosan. Hal ini disebabkan karena pengguna dapat melakukan pembayaran dengan sangat mudah dan cepat sehingga cenderung menggunakan aplikasi e-money tanpa berpikir lebih jauh (Ramadhan et al., 2016). Promosi dan diskon yang ditawarkan oleh pengembang e-money dapat menjerumuskan penggunanya kearah konsumtif jika mereka tidak melakukan kontrol yang baik dalam penggunaan e-money tersebut.

Mahasiswa merupakan kelompok masyarakat generasi $\mathrm{Z}$ yang dalam kehidupan sosialnya sehari-hari tidak terlepas dari gawai digital. Penelitian yang dilakukan oleh Badri (2020) menemukan bahwa generasi $Z$ di Pekanbaru merupakan pengguna aktif smartphone yang mengetahui dan menggunakan aplikasi dompet digital, yang mana merupakan aplikasi penyimpan $e$ money. Generasi $\mathrm{Z}$ yang saat ini termasuk dalam populasi penduduk dalam rentang umur remaja, sangat rentan dengan isu kontrol diri dan konsumtif. Lina dan Rosyid (1997), menyebutkan bahwa masa remaja merupakan masa peralihan dari masa anak- anak ke masa dewasa, sehingga dari segi psikisnya masih sangat belum mantap sehingga mudah untuk dipengaruhi. Dengan adanya gawai digital, Berbagai kegiatan dapat diakses oleh para remaja seperti kursus ketrampilan atau mata pelajaran melalui aplikasi digital, dan juga akses menuju marketplace serta e-money. Ramadani (2016) mengungkapkan promosi dan diskon yang ditawarkan oleh marketplace mampu membuat mahasiswa lebih konsumtif dikarenakan merasa mendapat keuntungan apabila melakukan transaksi itu selama masa promo masih berlangsung. Sedangkan jika dilewatkan maka mahasiswa sebagai pengguna e-money merasa akan kehilangan penawaran harga terbaik yang bisa mereka dapatkan. Meningkatnya aktivitas berbelanja online juga mampu memicu peningkatan penggunaan e-money. Mahasiswa lebih memilih untuk menggunakan transaksi dengan metode digital payment karena berbagai pertimbangan seperti lebih cepat, praktis, dan aman untuk digunakan. Disamping itu terdapat banyak potonganpotongan harga dalam bentuk poin atau penawaran belanja yang menarik. Searah dengan hasil penelitian Ramadani (2016), wawancara yang dilakukan oleh Ulayya dan Mujiasih (2020) dalam penelitiannya mengungkapkan bahwa mahasiswa sangat ter- 
bantu dengan hadirnya e-money yang dianggap memiliki kepraktisan dan kemudahan dalam pembayaran dimana dan kapanpun. Selain itu para mahasiswa promo cash back yang diberikan oleh layanan emoney mampu mempengaruhi keputusan mahasiswa dalam membeli suatu produk, karena mereka merasa hal tersebut akan menguntungkan mereka. Promosi yang diberikan ini mengakibatkan sebagian besar mahasiswa kurang mampu mengontrol pengeluaran, mereka cenderung membeli tanpa berpikir lebih panjang tentang kebutuhan dan kegunaan tersebut.

Penelitian dari Fatmasari dan Wulandari (2016) yang menyebutkan Perkembangan e-money pada kalangan remaja dapat mengubah perilaku individu dalam melakukan kegiatan konsumsi. Konsumen memiliki akses yang luas dalam melakukan transaksi keuangan dikarenakan faktor kemudahan dan kepraktisan dalam menggunakan e-money tersebut, trend inilah yang ditanggapi secara positif oleh mahasiswa.

Penggunaan e-money secara berlebihan dapat memicu perilaku konsumtif. Perilaku konsumtif sering dikaitkan dengan pola konsumsi barang atau jasa yang berlebihan, diluar batas kebutuhan seseorang. Perilaku konsumtif dapat diartikan sebagai suatu tindakan untuk membeli barang atau jasa secara terus menerus secara tidak rasional, tanpa mempertimbangkan aspek kegunaannya, sehingga yang ditonjolkan adalah status, prestige, kekayaan, keistimewaan dan hal lain yang mencolok (Triyaningsih dan Slamet, 2011). Anjani dan Astiti (2020) juga mengungkapkan bahwa perilaku konsumtif juga dapat didasarkan atas suatu barang yang menjadi bagian dari kegemaran individu, terlebih jika individu tersebut bergabung dalam komunitas penggemar, misalkan komunitas penggemar anime. Hal ini dapat menjadi media yang cukup berpengaruh bagi remaja dalam mengekspresikan diri, termasuk dalam berprilaku konsumtif.

Untuk itu perilaku konsumtif yang mengorbankan kebutuhan dimasa depan demi penawaran diskon yang menarik di masa kini, dapat menjerumuskan seseorang kedalam kondisi ksehatan keuangan yang buruk, selain itu perilaku konsumtif harus dihindari karena dapat menimbulkan masalah keuangan yang lebih mendalam di kemudian hari.

Penggunaan e-money bisa membawa kecenderungan perilaku keuangan yang tidak baik dalam hal ini perilaku konsumtif atau yang biasa disebut boros. Hal ini disebabkan karena pada saat bertransaksi online, secara psikologis tidak merasa mengeluarkan uang, sehingga menimbulkan suatu kecanduan untuk melakukan pembelajaan secara berulang. Sebenarnya pembelajaan berulang, atau sikap boros tidak selalu memiliki konotasi yang buruk. Akan tetapi pada sisi lainnya, pembelanja yang loyal akan meningkatkan perekonomian khususnya jika pengguna e-money mengeluarkan uangnya untuk berbelanja pada produk usaha mikro, kecil dan menengah (UMKM). Namun, sikap boros akan menjadi masalah, jika seseorang tidak mampu mengelola keuangannya. Dalam hal ini, seseorang tidak memiliki cukup uang namun tetap gila belanja sehingga harus berutang atau melakukan tindakan kecurangan lainnya. Hal inilah yang harus dihindari dari sikap boros tersebut. Oleh karena itu dibutuhkan kontrol diri yang kuat agar seseorang dalam mampu mengendalikan hasrat penggunaan e-money yang menjurus ke arah konsumtif.

Kontrol diri atau self control merupakan kemampuan dan kecakapan seseorang dalam mengendalikan tingkah laku dengan cara menekan, mengatur, atau mengarahkan suatu keinginan dengan berbagai pertimbangan. Hal ini dilakukan agar menghindari suatu keputusan yang salah atau bertentangan dengan norma-norma yang berlaku di masyarakat. Semakin baik kontrol diri yang dimiliki seseorang, maka semakin kuat pengendalian tingkah laku yang membawa seseorang ke dalam perilaku yang positif Goldfred dan Merbaum, 1973 dalam (Pervin, Cervone dan John, 2010). Menurut Ghufron 
dan Suminta, (2017) setiap individu memiliki suatu mekanisme yang dapat membantu mengatur dan mengarahkan perilaku yaitu kontrol diri. Selain itu, melalui kontrol diri mahasiswa mampu menahan keinginankeinginan yang muncul secara berlebihan dalam diri.

Dengan adanya fenomena kemudahan bertransaksi dengan e-money tentu saja akan membawa dampak positif dan negatif kepada mahasiswa yang menggunakannya. Dampak negatif yang dapat ditimbulkan adalah adanya kemungkinan perilaku konsumtif pada mahasiswa. Untuk itu diharapkan kontrol diri mampu menekan atau mengendalikan perilaku konsumtif yang dapat menimbulkan masalah keuangan dimasa yang akan datang.

Penelitian dari Nisa (2017) menunjukkan apabila kontrol diri meningkat maka perilaku konsumtif mahasiswa akan menurun. Beberapa hasil penelitian lainnya juga menunjukkan kontrol diri atau self control berpengaruh signifikan terhadap perilaku keuangan seseorang (Achtziger et al., 2015); (Strömbäck et al., 2017). Seseorang yang memiliki kontrol diri yang baik, cenderung menghemat uang, memiliki perilaku keuangan yang lebih baik dan memiliki rasa aman terhadap situasi keuangan saat ini maupun dimasa yang akan datang. Selain itu orang dengan kontrol diri yang tinggi memiliki efek positif pada perilaku menabung (Liu et al., 2019). Akan tetapi hasil penelitian dari Ramadhani (2019) menunjukkan saat kontrol diri meningkat, tidak serta merta berpengaruh pada menurunnya prilaku konsumtif mahasiswa. Hal ini dikarenakan mahasiswa merupakan remaja yang belum mampu mengendalikan diri dengan stabil. Hasil penelitian di atas, menunjukkan adanya inkonsitensi terhadap arah hubungan kontrol diri terhadap perilaku keuangan, yang dalam hal ini dikaitkan dengan perilaku konsumtif mahasiswa.

Berdasarkan latar belakang masalah tersebut, penelitian ini mengkaji penggunaan e-money terhadap perilaku konsumtif mahasiswa yang dimediasi kontrol diri.
Dengan kontrol diri, penggunaan e-money yang cenderung berdampak pada perilaku konsumtif dapat ditekan atau dikendalikan.

Berdasarkan paparan tersebut di atas, rumusan masalah yang diajukan dalam penelitian ini antara lain sebagai berikut.

1. apakah penggunaan e-money berpengaruh terhadap perilaku konsumtif pada mahasiswa;

2. apakah kontrol diri berpengaruh terhadap perilaku konsumtif pada mahasiswa;

3. apakah kontrol diri mampu memediasi penggunaan e-money terhadap perilaku konsumtif pada mahasiswa.

\section{TINJAUAN TEORETIS e-Money}

Peraturan mengenai e-money telah disusun dan disahkan oleh Bank Indonesia dengan Peraturan No.11/12/PBI/2009 pada tanggal 13 April 2009 tentang Uang Elektronik (Electronic Money). Hal yang menjadi pertimbangan akan adanya peraturan ini adalah karena adanya perkembangan alat pembayaran elektronik, adanya alat pembayaran yang diterbitkan oleh lembaga selain bank dan juga untuk meningkatkan kelancaran dan keamanan seluruh pengguna dan penyelenggara e-money. Menurut peraturan dari Bank Indonesia tersebut yang dimaksud sebagai e-money adalah alat pembayaran yang memenuhi unsur seperti:

a. diterbitkan atas dasar nilai uang yang disetor terlebih dahulu oleh pemegang kepada penerbit;

b. nilai uang disimpan secara elektronik dalam suatu media seperti server atau chip;

c. digunakan sebagai alat pembayaran kepada pedagang yang bukan merupakan penerbit uang elektronik tersebut; dan

d. nilai uang elektronik yang disetor oleh pemegang dan dikelola oleh penerbit bukan merupakan simpanan sebagaimana dimaksud dalam undang-undang yang mengatur mengenai perbankan.

Mengingat e-money memiliki fungsi seperti uang, maka untuk memberikan per- 
lindungan kepada Pemegang, meningkatkan kepercayaan masyarakat terhadap instrumen pembayaran e-money, dan mendukung kelancaran tugas Bank Indonesia dalam menjaga stabilitas moneter, Bank Indonesia menetapkan persyaratan yang wajib dipenuhi oleh Bank dan Lembaga Selain Bank dalam menyelenggarakan e-money.

Selain itu untuk mendukung upaya pemerintah dalam mencegah terjadinya tindak pidana pencucian uang dan pendanaan teroris, Bank Indonesia menetapkan batasan-batasan tertentu dalam e-money, antara lain nilai nominal yang dapat disimpan dalam e-money dan penerapan prinsip mengenal nasabah (know your customer principles).

Penerbitan e-money wajib menggunakan satuan uang rupiah. Disamping itu, setiap penggunaan e-money di wilayah Republik Indonesia wajib menggunakan uang rupiah. kewajiban penggunaan satuan uang rupiah didasarkan pada pertimbangan bahwa Nilai e-money harus dapat dikonversi secara penuh (fully convertible) sehingga nilai satu rupiah pada nilai e-money harus sama dengan satu rupiah pada uang tunai.

Untuk menjamin keamanan dan kelancaran penyelenggaran e-money, Bank Indonesia juga mengatur kewajiban-kewajiban yang harus dipenuhi oleh seluruh penyelenggara e-money seperti kewajiban penerapan manajemen risiko, pelaporan, dan keamanan sistem dalam Peraturan Bank Indonesia ini.

Ulayya dan Mujiasih (2020) mengungkapkan bahwa e-money pada hakikatnya merupakan uang tunai yang dikonversi kedalam data elektronik yang disimpan pada kartu penyimpanan berupa chip atau server, sehingga fungsi e-money tidak jauh berbeda dengan fungsi uang tunai.

e-money adalah salah satu produk keuangan digital, yang mana merupakan alternative pembayaran non tunai yang lebih efektif dari pembayaran tunai. Untuk mempermudah akses pada e-money, maka e-money ini umumnya disimpan dalam dompet digital (e-Wallet). Kemudahan, keamanan serta efesiensi serta inovatifnya emoney yang tersimpan dalam e-wallet mempengaruhi sikap konsumtif mahasiswa yang menggunakannya (Kumala dan Mutia, 2020).

Dompet digital (e-wallet) adalah layanan elektronik yang menyimpan data instrument pembayaran berupa kartu atau uang elektronik yang dimanfaatkan untuk menampung dana pembayaran. E-wallet membutuhkan gadget untuk menyambungkan pengguna ke server saat bertransaksi, sedangkan e-money berbasis chip yang ditanamkan di dalam kartu sehingga tidak memerlukan dukungan konektivitas jaringan internet ke server saat bertransaksi (Febrilia et al., 2020).

Bank Indonesia (Sihombing, 2017) dalam peraturan nomer 18/40/PBI/2016 menyebutkan bahwa Dompet Digital (electronic wallet) adalah layanan elektronik untuk menyimpan data instrument pembayaran antara alat pembayaran dengan menggunakan kartu atau uang elektronik, yang dapat menampung dana, untuk melakukan pembayaran. Aulia (2020) menyebutkan ada beberapa e-wallet yang berkembang di Indonesia, seperti GoPay, Ovo, DANA, LinkAja, Sakuku, Jenius, OCTO Go Mobile, DOku, Mega Mobile, dan iSaku.

Definisi operasional variabel e-money dalam penelitian ini adalah segala jenis layanan uang digital, tanpa membedakan apakah itu dompet digital ataukah hanya nilai uang digital, seperti misalnya mbanking, ovo, gopay, shopeepay, isaku, dan lain sebagainya.

Berdasarkan penelitian yang dilakukan oleh Ramadhani (2019) Indikator e-money dalam penelitian ini berupa:

1. Manfaat dan keuntungan. Manfaat penggunaan teknologi informasi didapat dari kepercayaan pengguna teknologi informasi dalam memutuskan penerimaan teknologi informasi, dengan satu kepercayaan bahwa teknologi informasi tersebut akan memberikan dampak positif atau keuntungan dalam pe- 
kerjaannya. Persepsi manfaat mengacu pada sejauh mana seseorang percaya bahwa menggunakan teknologi akan menguntungkan aktivitasnya.

2. Kemudahan dalam penggunaan adalah salah satu hal yang menjadi pertimbangan bagi masyarakat dalam menggunakan layanan electronic money. Kemudahan penggunaan merupakan seberapa besar teknologi informasi dirasakan relatif mudah untuk dipahami dan digunakan.

3. Kepercayaan. Uang elektronik merupakan sebuah produk yang cukup baru di masyarakat, oleh karena itu kepercayaan menjadi faktor yang sangat penting dalam penggunaannya. Pihak penerbit harus mengutamakan kepuasan pelanggan agar dapat membuat masyarakat percaya dengan produk electronic money yang diterbitkannya.

\section{Perilaku Konsumtif}

Perilaku merupakan tanggapan atau reaksi individu terhadap rangsangan atau lingkungan. Perilaku manusia merupakan hasil daripada segala macam pengalaman serta interaksi manusia dengan lingkungannya yang terwujud dalam bentuk pengetahuan, sikap dan tindakan. Terdapat suatu model hubungan perilaku yaitu $B=f(P, E)$, yang artinya bahwa perilaku (B) adalah fungsi dari karakteristik individu (P) dan lingkungan (E) (Azwar, 2013). Hal ini dapat dicermati bahwa perilaku seseorang merupakan kombinasi dari kepribadian dan lingkungannya.

Pendapat serupa dijelaskan melalui psikologi kepribadian yang menyatakan bahwa perbedaan individu disebabkan karena dua hal yaitu nature (bawaan) dan nurture (yang didapat dari asuhan atau belajar) (Lawrence et al., 2010). Artinya kita dapat menjadi diri kita sekarang disebabkan karena bawaan biologis atau fitur biologis yang kita miliki dan di sisi lain kepribadian juga berasal dari pengasuhan atau pengalaman yang diperoleh semasa anak-anak. Kedua faktor tersebut (nature dan nurture) bukanlah dua hal yang terpisah satu sama lain, namun merupakan faktor yang dapat mempengaruhi kepribadian melalui interaksi satu dengan yang lainnya. Faktor biologis dan lingkungan bukan kekuatan yang saling bersaing, tetapi faktor yang saling berinteraksi dan tak jarang saling melengkapi dan mempengaruhi kepribadian seseorang. Demikian halnya perilaku konsumtif dapat dipengaruhi oleh faktor lingkungan dalam hal ini penggunaan emoney dan faktor bawaan individu itu sendiri yaitu kontrol diri.

Haryani dan Herwanto (2015) menyatakan bahwa perilaku konsumtif adalah bentuk perilaku membeli suatu produk tanpa pertimbangan rasional atau bukan berdasarkan atas kebutuhan, seperti membeli barang karena hadiah yang ditawarkan, atau membeli barang karena banyak orang yang menggunakan barang tersebut.

Dikria dan Mintarti (2016) mengartikan perilaku konsumtif sebagai kecenderungan membeli atau mengonsumsi suatu barang yang sebenarnya kurang diperlukan secara berlebihan, serta tidak didasarkan atas pertimbangan yang rasional, sehingga faktor keinginan lebih dipentingkan daripada kebutuhan.

Hasil riset yang dilakukan oleh Enrico et al., (2014) menunjukkan beberapa faktor yang mampu mempengaruhi perilaku perilaku konsumtif, yaitu:

a. Masa kegunaan barang dan kemampuan untuk membeli.

b. Status sosial.

c. Kepuasan terhadap produk.

d. Gengsi

Dari penjabaran teori serta penelitian sebelumnya, maka definisi operasional variabel untuk perilaku konsumtif adalah kesediaan responden dalam memenuhi keinginannya dalam mengkonsumsi barang atau jasa diluar batas kebutuhannya. Berdasarkan penelitian yang dilakukan oleh Ramadhani (2019) Indikator perilaku konsumtif dalam penelitian ini berupa:

1. Pembelian produk karena iming-iming hadiah 
2. Pembelian produk karena kemasan yang menarik

3. Pembelian produk demi menjaga penampilan diri dan gengsi

4. Pembelian produk atas pertimbangan harga bukan karena berdasarkan manfaat dan kegunaan

5. Pembelian produk hanya sekedar menjaga status

6. Pemakaian produk karena unsur konformitas terhadap model yang mengiklankan

7. Penilaian diri membeli produk mahal menimbulkan rasa percaya diri yang tinggi

8. Mencoba lebih dari dua produk sejenis dengan merek berbeda

\section{Kontrol Diri}

Kontrol diri merupakan suatu kemampuan individu untuk mengukur perilaku dalam melakukan tindakan efektif yang dapat membawa individu membuat keputusan yang tepat dalam berkonsumsi agar tidak menimbulkan sikap konsumtif. Dikria dan Mintarti (2016). Tripambudi dan Indrawati, (2018) mengungkapkan dalam penelitiannya bahwa kontrol diri merupakan hal yang penting dalam diri individu, yang mana hal ini terkait dalam kemampuan menahan godaan dan nafsu sehingga dapat membantu individu tersebut dalam menjalankan tindakan yang bermoral sesuai dengan lingkungan sosial. Individu dengan kontrol diri yang tinggi lebih memperhatikan strategi berperilaku yang tepat, dalam situasi yang bervariasi (Haryani dan Herwanto, 2015).

Kumalasari dan Soesilo (2019) dalam penelitiannya mengungkapkan bahwa kontrol diri adalah suatu potensi yang dimiliki oleh seorang individu untuk menghadapi kondisi sekitarnya, serta sebagai pengendali dalam memutuskan suatu tindakan. Dewi et al., (2017) dalam penelitiannya mengungkapkan bahwa pengendalian diri atau kontrol diri dalam mengelola keuangan merupakan aktivitas yang mendorong seseorang untuk berhemat dengan menurun- kan perilaku konsumtifnya. Haryani dan Herwanto (2015) menyebutkan terdapat aspek-aspek dalam konrol diri, yaitu kemampuan mengontrol perilaku, kemampuan mengontrol kognitif dan kemampuan mengontrol keputusan. Sedangkan faktorfaktor yang mempengaruhi kontrol diri adalah usia, kematangan serta faktor keluarga. Berdasarkan teori dan penelitian sebelumnya, definisi operasional variabel kontrol diri dalam penelitian ini adalah tindakan kontrol diri responden terkait menghadapi transaksi keuangan.

Indikator kontrol diri dalam penelitian ini merujuk pada penelitian sebelumnya oleh Ramadhani (2019), yang terdiri atas beberapa poin berikut ini.

1. Kontrol perilaku yang merupakan kesiapan tersedianya suatu respon yang dapat secara langsung mempengaruhi sesuatu yang tidak menyenangkan. Kemampuan mengontrol perilaku dibagi menjadi dua komponen, yaitu mengatur pelaksanaan (regulated administration) yang merupakan kemampuan individu untuk mengatur siapa yang mengendalikan situasi, apakah dirinya sendiri atau aturan perilaku. Jika diri sendiri tidak mampu maka akan menggunakan faktor eksternal untuk mengendalikannya. Berikutnya adalah kemampuan memodifikasi stimulus (stimulus modifiability) yang merupakan kemampuan untuk mengatur stimulus atau respon bagaimana situasi yang tidak dikehendaki dihadapi.

2. Kontrol kognitif (cognitive control) yang merupakan kemampuan individu dalam mengontrol informasi yang tidak dikehendaki dengan cara mengintrepretasi, menilai atau menghubungkan suatu kejadian kedalam kerangka kognitif untuk mengurangi tekanan. Melakukan penilaian terhadap sesuatu berarti individu telah berusaha menilai atau menafsirkan keadaan dengan memperhatikan segi-segi positif.

3. Kontrol keputusan (decisional control) yang merupakan kemampuan individu 
untuk memilih hasil atau suatu tindakan berdasarkan yang diyakini atau disetujuinya. Pengendalian diri dalam menentukan pilihan akan berfungsi baik dengan adanya suatu kesempatan, kebebasan, atau kemungkinan pada diri individu untuk memilih berbagai kemungkinan tindakan.

\section{e-Money dan Perilaku Konsumtif}

Pada dasarnya perilaku konsumtif adalah perilaku yang tidak lagi berdasarkan pada pertimbangan yang rasional, melainkan karena adanya keinginan yang sudah mencapai taraf yang sudah tidak rasional lagi. Dalam hal ini perilaku belanja yang tidak dapat lagi membedakan antara kebutuhan dan keinginan. Kelompok usia remaja adalah salah satu pasar yang potensial bagi produsen. Alasannya, antara lain karena pola konsumsi seseorang terbentuk pada usia remaja. Di samping itu, remaja biasanya mudah terbujuk rayuan iklan, suka ikut-ikutan teman, tidak realistis, dan cenderung boros dalam menggunakan uangnya. Sifat-sifat remaja inilah yang dimanfaatkan oleh sebagian produsen untuk memasuki pasar remaja. Di kalangan remaja yang memiliki orangtua dengan kelas ekonomi yang cukup berada, terutama di kota-kota besar, "mall" sudah menjadi rumah kedua. Mereka ingin menunjukkan bahwa mereka juga dapat mengikuti mode yang sedang berkembang. Padahal mode itu sendiri selalu berubah sehingga para remaja tidak pernah puas dengan apa yang dimilikinya.

Di era digital dewasa ini, peran uang elektronik (e-money) turut mempengaruhi perilaku konsumtif yang terjadi di masyarakat. e-money merupakan alat pembayaran yang memenuhi unsur-unsur sebagai berikut: diterbitkan atas dasar nilai uang yang disetor terlebih dahulu oleh pemegang kepada penerbit, nilai uang disimpan secara elektronik dalam suatu media seperti server atau chip, digunakan sebagai alat pembayaran kepada pedagang yang bukan merupakan penerbit uang elektronik ter- sebut, dan nilai uang elektronik yang disetor oleh pemegang dan dikelola oleh penerbit bukan merupakan simpanan sebagaimana dimaksud dalam undang-undang yang mengatur mengenai perbankan.

Penggunaan e-money pada dasarnya dapat mengakibatkan dampak positif dan negatif pada penggunanya. Dampak positif yang dirasakan adalah kemudahan dalam melakukan transaksi dan resiko kehilangan akibat tindakan kejahatan seperti pencurian dan perampokan dapat dihindari. Di sisi lain penggunaan e-money juga berdampak negatif yaitu perilaku konsumtif. Ramadani (2016) menyebutkan bahwa pengeluaran konsumsi dipengaruhi oleh beberapa faktor, salah satunya adalah perkembangan teknologi, yang mana perkembangan teknologi ini memicu arus transaksi non tunai.

Ulayya dan Mujiasih (2020) menyebutkan semakin mudahnya transaksi jual-beli dengan e-money saat ini membuat masyarakat rentan dengan perilaku konsumtif, khususnya pada remaja, yang mana mereka harus mengontrol diri dari budaya konsumtif yang semakin berkembang. Selain itu, beberapa kajian juga menujukkan bahwa penggunaan e-money memiliki pengaruh terhadap perilaku keuangan maupun perilaku konsumtif pada mahasiswa (Ramadani, 2016);

\section{Kontrol Diri dan Perilaku Kosumtif}

Kontrol diri pada dasarnya penggambaran diri seseorang untuk memahami seberajauh hubungan antara tindakan yang dilakukan dengan akibat yang terjadi atas tindakan tersebut. Kontrol diri dalam keuangan memiliki makna kemampuan atau kecakapan seseorang dalam mengendalikan keuangannya. Sering kali seseorang hanya berpikir tentang keuangan jangka pendek saja, dalam hal ini terdapat kecenderungan untuk membelanjakan semua penghasilan bahkan melebihi penghasilan itu sendiri (melalui utang). Untuk itu kontrol diri berperan menekan pengeluaran yang tidak terencana serta adanya tindakan untuk mulai menata tujuan keuangan untuk masa 
depan. Penelitian Kumalasari dan Soesilo (2019) menyatakan semakin tinggi kontrol diri maka akan semakin intens pengendalian seseorang terhadap tingkah laku dalam berkonsumsi agar terhindar dari sikap konsumtif.

Haryani dan Herwanto (2015) menyebutkan perilaku konsumtif banyak melanda kehidupan remaja, yang mana pada dasarnya remaja masih banyak yang belum berpendapatan. Akan tetapi Remaja banyak dijadikan target pemasaran dikarenakan karakteristik remaja yang labil dan mudah dipengaruhi sehingga menimbul kan sikap konsumtif yang diluar kebutuhan.

Beberapa hasil penelitian lainnya juga menunjukkan pengaruh antara kontrol diri dan perilaku konsumtif (Liu et al., 2019; Strömbäck et al., 2017; Novak et al., 2000; Dikria dan Mintarti, 2016; Dewi et al., 2017; Fattah et al., 2018; Haryani dan Herwanto 2015; Nisa, 2017). Semakin tinggi kontrol diri yang dimiliki seseorang maka perilaku keuangannya menunjukkan arah yang positif termasuk didalamnya menurunnya perilaku konsumtif seseorang. Berdasarkan landasan teori yang dikemukakan di atas, maka terdapat beberapa hipotesis yang diajukan dalam penelitian ini antara lain sebagai berikut.

$\mathrm{H}_{1}$ : Penggunaan e-money berpengaruh langsung terhadap perilaku konsumtif pada mahasiswa.

$\mathrm{H}_{2}$ : Kontrol diri berpengaruh langsung terhadap perilaku konsumtif pada mahasiswa.

$\mathrm{H}_{3}$ : Penggunaan e-money berpengaruh tidak langsung terhadap perilaku konsumtif pada mahasiswa melalui kontrol diri.

\section{METODE PENELITIAN \\ Rancangan Penelitian}

Penelitian ini menggunakan paradigma kuantitatif yang menguji teori-teori melalui pengukuran variabel-variabel penelitian dengan angka dan melakukan analisis data dengan prosedur statistik. Dalam Gambar 1. Menggambarkan bagaimana variabel penggunaan e-money dan kontrol diri memiliki pengaruh terhadap perilaku konsumtif mahasiswa Program Studi Akuntansi.

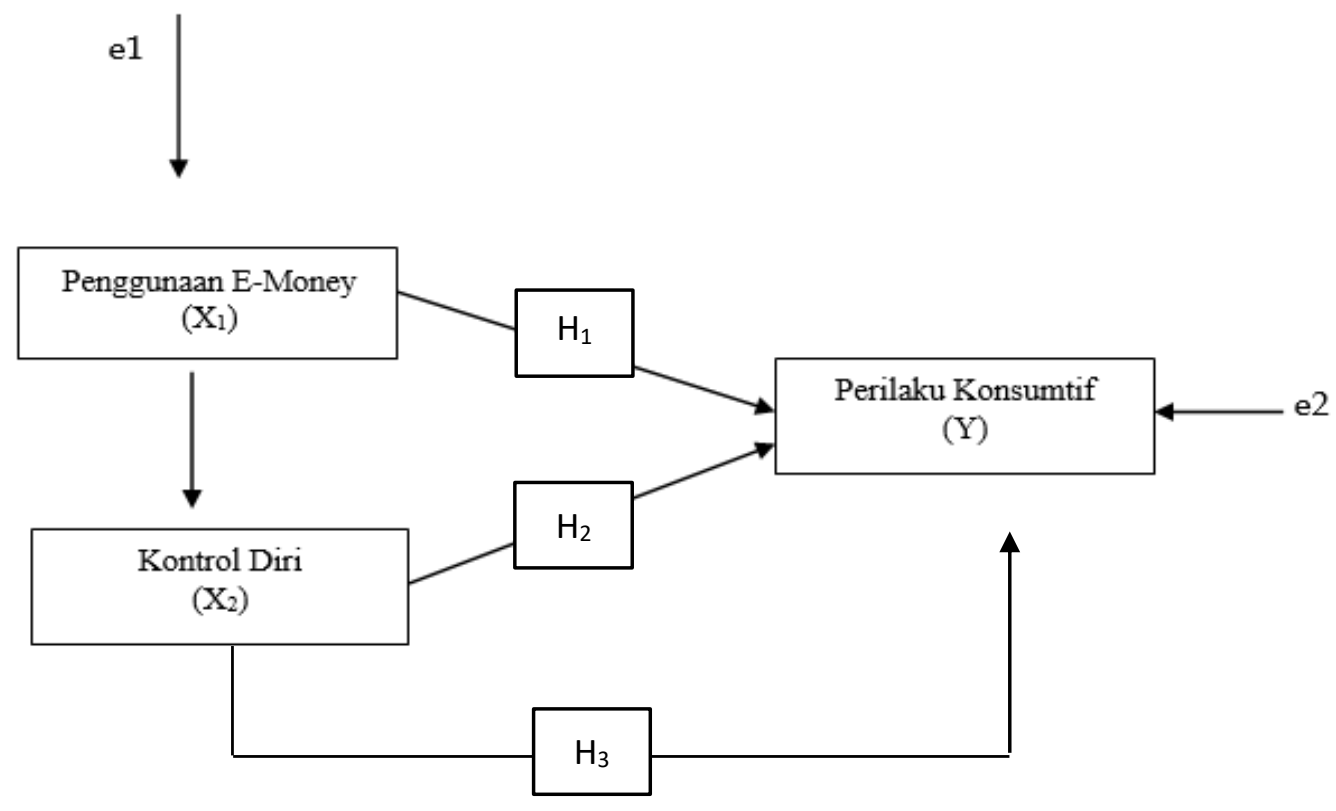

Gambar 1

Rerangka Penelitian 


\section{Populasi dan Sampel}

Populasi dalam penelitian ini adalah seluruh mahasiswa pada universitasuniversitas yang ada di Bali. Pulau Bali terdiri dari dua wilayah utama yaitu wilayah Bali Utara dan Wilayah Bali Selatan. Kedua wilayah ini dipisahkan oleh pengunungan dan perbukitan yang terletak ditengahtengah pulau, melintang dari bagian barat hingga bagian timur pulau Bali. Ibu Kota Provinsi Bali terdapat di daerah Bali selatan. Bukan hanya di daerah Ibu Kota Provinsi (kota Denpasar), Universitas sebagai gerbang ilmu pendidikan bagi generasi milenial juga terdapat di kawasan Bali Utara. Walaupun sektor pariwisata Bali selatan lebih populer, yang berimbas pada peningkatan perputaran perekonomian masyarakat sekitarnya.

Akan tetapi, melalui observasi di Bali Utara, khususnya daerah Kota Singaraja, dapat dilihat bahwa banyaknya pertokoan modern lokal hingga gerai waralaba internasional yang menawarkan berbagai produk barang atau jasa. Sehingga dapat disimpulkan adanya alur konsumsi yang tinggi di Kawasan kota Singaraja, yang tidak kalah dengan kota lain di Bali Selatan. Kota Singaraja merupakan lokasi dimana salah satu Universitas negeri berada, yang mahasiswanya juga dimasukkan kedalam populasi penelitian ini.

Teknik pengambilan sampel menggunakan simple random sampling yaitu setiap mahasiswa pengguna e-money yang bersedia mengisi kuesioner penelitian, tanpa melihat asal fakultas, tahun angkatan ataupun tingkat keuangan mahasiswa. Untuk kecukupan sampel mengacu pada Tabel Nomogram Harry A. King (King, 1978) Berdasarkan teknik pengambilan sampel di atas, maka jumlah sampel yang dapat digunakan dalam penelitian ini adalah sebanyak 354 orang responden pengguna $e$ money, dengan rincian 260 orang responden dari Undiksha, 40 orang Responden dari Unwar, 37 orang Responden dari Unhi, dan 9 orang responden dari universitas-universitas lainnya.

\section{Teknik Pengumpulan Data}

Pengumpulan data dalam penelitian ini menggunakan kuesioner. Kuesioner merupakan teknik pengumpulan data yang dilakukan dengan cara memberikan seperangkat pertanyaan atau pernyataan tertulis kepada responden untuk dijawab, yaitu untuk intsrumen penggunaan $e$-money, kontrol diri, dan perilaku konsumtif. Kuesioner disusun dengan menggunakan skala Likert 6 (enam) poin yang bergerak dari 1 s/d 6. Butir pernyataan diberikan skor, sangat tidak setuju (1), hingga sangat setuju (6). Kuesioner dibuat menggunakan aplikasi google form dan disebarkan ke forum diskusi mahasiswa di masing-masing Universitas. Penggunaan google form dipilih untuk mengefektifkan dan efesiensi sumber daya serta waktu pengumpulan data. Sebelum digunakan, dilakukan pengujian validitas dan reliabilitas instrumen. Hasil pengujian menunjukkan kriteria valid untuk keseluruhan instrumen yaitu $r$ hitung $>r$ kritis 0,3 . Pengujian reliabilitas menunjukkan keseluruhan instrumen memiliki koefisien reliabilitas $>0,7$ sehingga dapat disimpulkan instrumen penelitian memiliki reliabilitas tinggi (Dantes, 2012).

\section{Teknik Analisis Data}

Data yang diperoleh melalui kuesioner dianalisis dengan menggunakan analisis statistik deskriptif dan analisis jalur (path analysis) berbantuan program SPSS for Windows versi 20. Statistik deskriptif, memberikan gambaran umum responden dan tingkat penggunaan e-money di kalangan mahasiswa di Provinsi Bali. Analisis berikutnya adalah analisis jalur (path analysis) yang digunakan untuk mencari pengaruh langsung antara penggunaan e-money dan kontrol diri terhadap perilaku konsumtif mahasiswa dan pengaruh tidak langsung penggunaan e-money terhadap perilaku konsumtif mahasiswa melalui kontrol diri.

\section{Definisi Operasional Variabel}

Definisi operasional variabel e-money dalam penelitian ini adalah segala jenis 
layanan uang digital, tanpa membedakan apakah itu dompet digital ataukah hanya nilai uang digital, seperti misalnya $\mathrm{m}$ banking, ovo, gopay, shopeepay, isaku, dan lain sebagainya.

Definisi operasional variabel kontrol diri adalah tindakan kontrol diri responden terkait menghadapi transaksi keuangan, dan definisi operasional variabel untuk perilaku konsumtif adalah kesediaan responden dalam memenuhi keinginannya dalam mengkonsumsi barang atau jasa diluar batas kebutuhannya.

\section{ANALISIS DAN PEMBAHASAN Deskripsi Data}

Dari 494 kuesioner yang terisi, sebanyak 354 responden menyatakan menggunakan $e$ money, dan sisanya tidak menggunakan $e$ money. Oleh karena itu hanya $71,65 \%$ data responden yang dapat dianalisis. Gambaran umum penggunaan e-money dapat dilihat pada Tabel 2 berikut ini.

Tabel 2

Gambaran Umum Penggunaan e-Money

\begin{tabular}{lccc}
\hline \hline \multicolumn{1}{c}{ Data } & M-Banking & $\begin{array}{c}\text { Selain M-Banking (Dana/iSaku/ } \\
\text { Gopay/Ovo/Lainnya) }\end{array}$ \\
\hline $\begin{array}{l}\text { Jenis } e \text {-Money yang } \\
\text { Digunakan }\end{array}$ & $\begin{array}{c}262 \text { orang } \\
\text { responden atau } \\
74 \%\end{array}$ & 92 orang atau $26 \%$ \\
\hline Data & Konsumtif & Pendidikan & $\begin{array}{c}\text { Pendidikan dan } \\
\text { Konsumtif }\end{array}$ \\
\hline Penggunaan $e$-Money & $\begin{array}{c}99 \text { orang } \\
\text { responden atau } \\
28 \%\end{array}$ & $\begin{array}{c}23 \text { orang } \\
\text { responden atau } \\
6 \%\end{array}$ & $\begin{array}{c}232 \text { orang responden } \\
\text { atau } 66 \%\end{array}$ \\
\hline
\end{tabular}

Sumber: data diolah

Dari Tabel 2 mengenai gambaran umum penggunaan e-money diatas, dapat dilihat bahwa sebanyak $74 \%$ atau 262 orang responden menggunakan e-money berupa layanan m-banking, sedangkan sisanya sebanyak $26 \%$ atau 92 orang menggunakan $e$ money selain layanan m-banking (Dana, Gopay, iSaku/Ovo/dan lainnya). Dari data ini dapat dilihat mayoritas mahasiswa lebih menggunakan layanan uang elektronik melalui m-banking daripada penyedia dompet digital lainnya.

Selain itu tujuan penggunaan e-money dikalangan mahasiswa sebagian besar adalah untuk keperluan pendidikan dan juga konsumtif $(66 \%)$, sedangkan untuk keperluan konsumtif saja sebesar $28 \%$, dan keperluan pendidikan saja adalah sebesar $6 \%$. Proses pengolahan data selanjutnya dilakukan dengan uji asumsi klasik untuk menguji keabsahan model regresi yang akan diujikan. Adapun uji asumsi yang digunakan adalah pengujian normalitas, heteroskedastisitas, dan uji multikolinieritas. Pengujian asumsi ini dilakukan pada 2 (dua) model regresi yang diajukan. Hasil pengujian normalitas menunjukkan nilai Kolmogorov Smirnov dengan nilai sig. > 0,05, sehingga dapat disimpulkan data berdistribusi normal. Dilanjutkan pengujian heteroskedastisitas menggunakan uji glejser menunjukkan nilai sig.> 0,05 sehingga dapat disimpulkan tidak mengandung heteroskedastisitas.

Terakhir pengujian multikolinieritas diperoleh nilai tolerance lebih besar dari $10 \%$ dan VIF dibawah 10 sehingga model regresi tidak terjadi multikolinieritas. Dengan dipenuhinya persyaratan uji asumsi klasik, maka model regresi dalam analisis jalur dapat dilanjutkan. Pengujian hipotesis menggunakan analisis jalur dengan 2 (dua) 
persamaan structural atau sub struktur dijelaskan berikut.

Pengaruh Penggunaan E-Money Terhadap Kontrol Diri Mahasiswa (Sub-Struktur 1)
Pengujian ini menganalisis pengaruh penggunaan e-money terhadap kontrol diri mahasiswa. Pengujian ini menggunakan analisis regresi sederhana yang hasilnya dapat dilihat Tabel 3 berikut ini.

Tabel 3

Hasil Analisis Regresi (Sub-Struktur 1)

\begin{tabular}{lcccc}
\hline \hline \multicolumn{1}{c}{ Variable } & $\begin{array}{c}\text { Standardized } \\
\text { Coefficients Beta }\end{array}$ & Std. Error & t- Statistik & Sig. \\
\hline Constant & - & 1,343 & 9,600 & 0,000 \\
Penggunaan E- & 0,369 & 0,066 & 7,456 & 0,000 \\
Money & & & & \\
R-Square & 0,136 & & & \\
Adjusted & & & & \\
R-Square & 0,134 & & & \\
F-Statistic & 55,597 & & & \\
Sig. F-Statistic & 0,000 & & & \\
\hline Dependet variabl & & & & \\
\hline
\end{tabular}

Dependet variable: Kontrol Diri Mahasiswa

Berdasarkan hasil pengujian regresi pada Tabel 3, berdasarkan uji t menghasilkan persamaan pertama yang diperoleh adalah: $\mathrm{X}_{2}=0,369 \mathrm{X}_{1} ; \mathrm{R}^{2}=0,136 ; \mathrm{e}=0,864\left(1-\mathrm{R}^{2}\right)$. Untuk itu persamaan jalurnya dapat dirumuskan sebagai berikut. X2 (kontrol diri) $=0,369 X 1+0,864 e 1 ; R^{2}=0,136$. Pengujian sub-struktur 1 digunakan untuk pengujian $\mathrm{H}_{3}$ yaitu pengaruh tidak langsung antara penggunaan e-money terhadap perilaku konsumtif melalui kontrol diri. Pengujian $\mathrm{H}_{1}$ dan $\mathrm{H}_{2}$ dapat dilihat dalam sub-struktur 2.

Pengaruh Penggunaan E-Money dan Kontrol Diri Terhadap Perilaku Konsumtif Mahasiswa (Sub Struktur-2)

Pengujian ini menganalisis pengaruh penggunaan e-money dan kontrol diri terhadap perilaku konsumtif mahasiswa. Pengujian ini menggunakan analisis regresi yang hasilnya dapat dilihat Tabel 4 berikut ini.

Tabel 4

Hasil Analisis Regresi

\begin{tabular}{|c|c|c|c|c|}
\hline Variable & $\begin{array}{c}\text { Standardized } \\
\text { Coefficients Beta }\end{array}$ & Std. Error & t- Statistik & Sig. \\
\hline Constant & - & 2,441 & 17,731 & 0,000 \\
\hline $\begin{array}{l}\text { Penggunaan E- } \\
\text { Money }\end{array}$ & 0,104 & 0,116 & 2,194 & 0,029 \\
\hline Kontrol Diri & $-0,600$ & 0,086 & $-12,703$ & 0,000 \\
\hline $\begin{array}{l}\text { R-Square } \\
\text { Adjusted R- }\end{array}$ & 0,324 & & & \\
\hline Square & 0,321 & & & \\
\hline F-Statistic & 84,292 & & & \\
\hline Sig. F-Statistic & 0,000 & & & \\
\hline
\end{tabular}

Dependet variable: Perilaku Konsumtif 
Berdasarkan hasil pengujian regresi pada Tabel 4 di atas, nilai $F$ sebesar 84,292 dengan sig. $0,000<0,005$, sehingga dapat disimpulkan secara simultan penggunaan $e$ money dan kontrol diri berpengaruh terhadap perilaku konsumtif mahasiswa. Persamaan jalurnya dapat dirumuskan sebagai berikut: $\mathrm{Y}$ (perilaku konsumtif) = $0,104 X_{1}-0,600 X_{2}+0,676$ e2; $R_{2}=0,324$. Selanjutnya pengujian koefisien jalur dari $\mathrm{X}_{1}$ ke $Y$ yaitu $P Y X_{1}$ yaitu sebesar 0,104 dengan nilai $\mathrm{p}$-value atau sig. $=0,029<0,05$, sehingga dapat disimpulkan bahwa Ho ditolak atau penggunaan e-money berpengaruh langsung terhadap perilaku konsumtif mahasiswa. Jadi dapat disimpulkan bahwa hipotesis $\mathrm{H}_{1}$ diterima, yaitu adanya pengaruh langsung yang signifikan antara penggunaan $e$-money terhadap perilaku konsumtif mahasiswa. Kooefisien yang bernilai positif $(0,104)$ menunjukkan arah hubungan yang positif juga.

Penelitian ini menunjukkan bahwa penggunaan e-money pada mahasiswa di Bali memiliki pengaruh positif dan signifikan terhadap perilaku konsumtif. Hasil ini sebenarnya dapat dilihat juga dalam satatistik deskriptif yang menunjukkan bahwa penggunaan e-money untuk kegiatan konsumtif lebih besar presentasenya (28\%) daripada kegiatan pendidikan $(6 \%)$. Hal ini juga didukung oleh penelitian yang menunjukkan bahwa penggerak ekonomi pasar website jual beli online atau melalui $e$ commerce di Bali merupakan kaum muda. Hasil penelitian menunjukkan remaja berumur 17-25 tahun menempati urutan pertama yaitu sebesar $44 \%$ dalam melakukan belanja online, sedangkan persentase terkecil yaitu $11 \%$ diperoleh dari responden yang berumur 40-55 tahun (Dwipayani dan Rahyuda, 2016). Hal ini menunjukkan bahwa mahasiswa yang termasuk golongan milenial memiliki kecenderungan untuk melakukan kegiatan belanja melalui $e$-commerce, yang kebanyakan pembayarannya dengan menggunakan $e$-money.

Perilaku konsumtif pada remaja sebenarnya dapat dimengerti bila melihat usia remaja sebagai usia peralihan dalam mencari identitas diri. Remaja ingin diakui eksistensinya oleh lingkungan dengan berusaha menjadi bagian dari lingkungan itu. Kebutuhan untuk diterima dan menjadi sama dengan orang lain yang sebaya itu menyebabkan remaja berusaha untuk mengikuti berbagai atribut yang sedang menjadi trend. Remaja dalam perkembangan kognitif dan emosinya masih memandang bahwa atribut yang superfisial itu sama penting (bahkan lebih penting) dengan substansi. Apa yang dikenakan oleh seorang artis yang menjadi idola para remaja menjadi lebih penting (untuk ditiru) dibandingkan dengan kerja keras dan usaha yang dilakukan artis idolanya itu untuk sampai pada kepopulerannya.

Hal inilah yang mendorong remaja untuk melakukan kegiatan konsumtif dan $e$ money merupakan sarana yang efektif untuk mewujudkannya. Hasil riset ini mendukung beberapa penelitian sebelumnya. Seperti penelitian dari (Ramadani, 2016); dan (Ulayya dan Mujiasih, 2020) yang menujukkan semakin tinggi penggunaan e-money maka perilaku konsumtifnya juga semakin tinggi.

Untuk pengujian hipotesis $\mathrm{H}_{2}$ dapat dilihat dari koefisien jalur dari $\mathrm{X}_{2}$ ke $\mathrm{Y}$ yaitu $\mathrm{PYX}_{2}$ yaitu sebesar - 0,600 dengan nilai $\mathrm{p}$ value atau sig. $=0,000<0,05$, sehingga dapat disimpulkan bahwa Ho ditolak atau kontrol diri berpengaruh langsung terhadap perilaku konsumtif mahasiswa. Jadi dapat disimpulkan bahwa hipotesis $\mathrm{H}_{2}$ diterima, yaitu adanya pengaruh langsung yang signifikan antara kontrol diri terhadap perilaku konsumtif mahasiswa. Nilai koefisien negatif $(-0,600)$ menunjukkan arah yang berlawanan, dengan makna semakin baik kontrol diri seseorang maka perilaku konsumtifnya akan semakin berkurang.

Kontrol diri pada dasarnya merupakan kemampuan yang dimiliki seseorang untuk membimbing tingkah laku diri untuk menekan atau merintangi impuls-impuls atau tingkah laku impulsif. Berdasarkan hasil penelitian ini menunjukkan kontrol diri 
mahasiswa tergolong sangat baik. Secara statistic deskriptif rata-rata kontrol diri mahasiswa sebesar 91 yang dapat dikategorikan sangat baik. Hal ini menunjukkan bahwa mahasiswa memiliki upaya-upaya untuk menekan hasrat untuk melakukan kegiatan konsumtif yang berlebihan.

Peran kontrol diri dalam perilaku konsumtif sangatlah penting. Hasil penelitian menunjukkan bahwa kontrol diri mampu mengarahkan dan mengatur individu untuk membelanjakan uangnya secara positif. Individu yang memiliki kontrol diri tinggi akan mampu mengatur perilaku belanjanya sesuai dengan kebutuhan dan bukan hanya memuaskan keinginan. Tidak mudah terpengaruh oleh tawaran penjual, tidak terpengaruh oleh diskon harga, percaya diri dengan penampilan sewajarnya, dan mampu menata uang dengan lebih efisien (Fitriana dan Koentjoro, 2009).

Hasil riset ini mendukung beberapa penelitian sebelumnya, seperti (Liu et al., 2019); (Strömbäck et al., 2017); (Novak et al. 2000); (Dikria dan Mintarti, 2016); (Dewi et al., 2017); (Fattah et al., 2018); (Haryani dan Herwanto (2015); (Nisa, 2017). Untuk menganalisis pengaruh tidak langsung variabel dalam model jalur dapat dilihat dalam ringkasan hasil dekomposisi dalam Tabel 5 dibawah ini.

Sedangkan persamaan sub-struktur 1 dan 2 dapat digambarkan dalam diagram jalur pada gambar berikut Gambar 2 .

Tabel 5

Ringkasan Dekomposisi Koefisien Korelasi

\begin{tabular}{cccccc}
\hline \hline No & Jalur & $\begin{array}{c}\text { Pengaruh } \\
\text { Langsung }\end{array}$ & Melalui & $\begin{array}{c}\text { Pengaruh tidak } \\
\text { Langsung }\end{array}$ & $\begin{array}{c}\text { Total } \\
\text { Pengaruh }\end{array}$ \\
\hline 1 & $\mathrm{X}_{1} \rightarrow \mathrm{X}_{2}$ & 0,369 & - & - & 0,245 \\
2 & $\mathrm{X}_{2} \rightarrow \mathrm{Y}$ & $-0,600$ & - & - & $-0,600$ \\
3 & $\mathrm{X}_{1} \rightarrow \mathrm{Y}$ & 0,104 & $\mathrm{X}_{2}$ & $-0,221$ & $-0,117$ \\
\hline
\end{tabular}

Sumber: data diolah

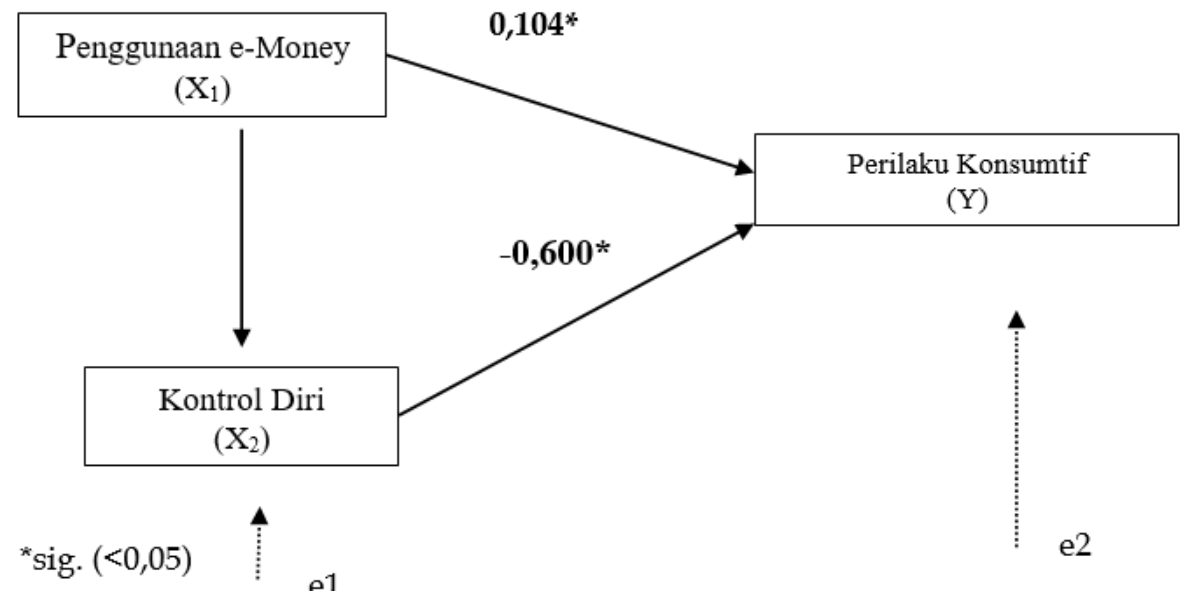

Gambar 2

Model Empirik Akhir Sub-Struktur 1 dan 2

Berdasarkan pengujian analisis jalur di atas, dapat dilihat pengaruh langsung dan tidak langsung dari penggunaan e-money terhadap perilaku konsumtif mahasiswa.
Terdapat penurunan koefiesien dari jalur dari 0,104 menjadi -0,117 atau dari yang bernilai positif menjadi negatif. Hal ini menunjukkan bahwa dengan kontrol diri, 
maka penggunaan e-money dapat menekan atau mengurangi perilaku konsumtif pada mahasiswa.

Untuk pengujian $\mathrm{H}_{3}$ signifikansi kontrol diri sebagai variabel mediasi dalam model dapat diperiksa dari hasil uji sobel dengan rincian pertama adalah mencari nilai koefisien jalur (estimate) dan standar error untuk masing-masing jalur. Kemudian dicari nilai standar error secara bersama antara kedua jalur tersebut dengan rincian sebagai berikut.

Tabel 6

Hasil Pengujian Hipotesis Mediasi 1

\begin{tabular}{lcc}
\hline \multicolumn{1}{c}{ Hubungan } & Koefisien Jalur & Standar Error \\
\hline E-Money $\rightarrow$ Kontrol Diri & 0,369 & 0,066 \\
Kontrol Diri $\rightarrow$ Perilaku Konsumtif & $-0,600$ & 0,086 \\
\hline
\end{tabular}

Deskripsi tabel di atas dapat diuraikan sebagai berikut:

$\mathrm{a}=0,369$,

$\mathrm{Sa}=0,066$

$\mathrm{b}=-0,600$

$\mathrm{Sb}=0,086$

Untuk menghitung Uji Sobel maka digunakan rumus seperti di bawah ini.

Menghitung standar Error ab atau Sab:

$S a b=\sqrt{b^{2} S a^{2}+a^{2} S b^{2}+S a^{2} S b^{2}}$

Menghitung nilai $\mathrm{t}$ koefisien ab:

$t=\underline{a b}$

$s a b$

Berdasarkan hasil perhitungan diperoleh nilai $t$ hitung untuk uji pengaruh mediasi pada hipotesis ini adalah $-4,363$. Jika $\mathrm{a}=0,05$ maka $\mathrm{t}$ tabel $=-1,96$. Dari perhitungan di atas dapat disimpulkan bahwa $\mathrm{t}$ hitung $(-4,363)$ lebih kecil dari -t tabel $(-1,96)$ dengan tingkat signifikansi 0,05 , maka dapat disimpulkan $\mathrm{H}_{3}$ diterima atau dapat dinyatakan bahwa kontrol diri mampu memediasi antara e-money dengan perilaku konsumtif. Dengan adanya kontrol diri, maka perilaku konsumtif akibat penggunaan e-money dapat dikendalikan atau dikurangi.

\section{SIMPULAN DAN SARAN Simpulan}

Berdasarkan hasil analisis dan pembahasan di atas, maka dapat disimpulkan beberapa hal sebagai berikut.

Pertama, penggunaan e-money berpengaruh langsung secara signifikan terhadap perilaku konsumtif mahasiswa.

Kedua, kontrol diri berpengaruh langsung terhadap perilaku konsumtif mahaiswa. Nilai koefisien negatif menunjukkan arah yang berlawanan, dengan makna semakin baik kontrol diri seseorang maka perilaku konsumtifnya akan semakin berkurang.

Ketiga, terdapat pengaruh tidak langsung antara penggunaan e-money terhadap perilaku konsumtif mahasiswa yang dimediasi oleh kontrol diri. Jadi dapat disimpulkan bahwa kontrol diri mampu memediasi antara e-money dengan perilaku konsumtif.

\section{Implikasi}

Hasil penelitian ini memberikan implikasi sebagai berikut.

Pertama, penggunaan e-money berpengaruh langsung secara signifikan terhadap perilaku konsumtif. Hal ini mengindikasikan agar para mahasiswa meningkatkan kontrol diri dalam mengimbangi penggunaan e-money, sehingga e-money bisa berfungsi sesuai dengan diharapkan (mempermudah transaksi mahasiswa) dan menghindari sisi buruknya. 
Kedua, dengan adanya kontrol diri, mahasiswa sebagai pengguna e-money juga dapat terhindar dari sikap konsumtif. Ketiga, kontrol diri mampu memediasi antara e-money dengan perilaku konsumtif dengan demikian jika mahasiswa memiliki kontrol diri yang tinggi, maka penggunaan e-money dapat menekan atau mengurangi perilaku konsumtif pada mahasiswa. Dalam artian, mahasiswa menggunakan e-money hanya sebatas kebutuhan saja, misalkan untuk pembayaran kuliah atau membeli kebutuhan primer lainnya.

\section{Keterbatasan Penelitian}

Penelitian ini hanya melibatkan beberapa universitas yang ada di Bali. Untuk kedepannya diharapkan agar dapat melibatkan lebih banyak universitas dan sekolah tinggi yang ada di Bali, sehingga lebih luas lagi cakupan populasi dan sampelnya. Metode survei menggunakan google form ada kalanya tidak sepenuhnya dapat mencerminkan keadaan responden secara utuh. Untuk itu, penambahan metode wawancara secara mendalam untuk melengkapi hasil penelitian, dapat dilakukan agar mendapat hasil yang lebih memuaskan.

\section{DAFTAR PUSTAKA}

Achtziger, A., M. Hubert, P. Kenning, G. Rabb, dan L. Reisch. 2015. Debt out of control: The links between self-control, compulsive buying, and real debts. Journal of Economic Psychology 49: 141149.

Anjani, P. S. dan D. P. Astiti. 2020. Hubungan kontrol diri dan konformitas terhadap perilaku konsumtif remaja penggemar animasi Jepang (anime) di Denpasar. Jurnal Psikologi Udayana 1: 144-155.

Aulia, S. 2020. Pola Perilaku Konsumen Digital Dalam Memanfaatkan Aplikasi Dompet Digital. Jurnal Komunikasi 12(2): 311-324.

Azwar, S. 2013. Sikap Manusia: Teori dan Pengukurannya. Pustaka Pelajar. Yogyakarta.

Badri, M. 2020. Adopsi Inovasi Aplikasi
Dompet Digital di Kota Pekanbaru. Inovbiz: Jurnal Inovasi Bisnis 8(1): 120-127. Bank Indonesia. 2009. Peraturan Nomor 11/12/PBI/2009 pada tanggal 13 April 2009 tentang Uang Elektronik (Electronic Money).

Dantes, N. 2012. Metode Penelitian. Penerbit Andi. Yogyakarta.

Dewi, N., Rusdarti, dan S. Sunarto. 2017. Pengaruh Lingkungan Keluarga, Teman Sebaya, Pengendalian Diri Dan Literasi Keuangan Terhadap Perilaku Konsumtif Mahasiswa. Journal of Economic Education 6(1): 29-35.

Dikria, O. dan S. U. Mintarti. 2016. Pengaruh Literasi Keuangan Dan Pengendalian Diri Terhadap Perilaku Konsumtif Mahasiswa Jurusan Ekonomi Pembangunan Fakultas Ekonomi Universitas Negeri Malang Angkatan 2013. Jurnal Pendidikan Ekonomi 9(2): 128-139.

Dwipayani, N. dan I. Rahyuda. 2016. Pengaruh Sikap Dan Fashion Leadership Terhadap Niat Beli Online Remaja Di Kota Denpasar. E-Jurnal Manajemen Unud 5(6).

Enrico, A., R. Aron, dan W. Oktavia. 2014. The Factors That Influenced Consumptive Behavior: A Survey of University Students in Jakarta. International Journal of Scientific and Research Publications 4(1): 99-104.

Fatmasari, D. dan S. Wulandari. 2016. Analisis Faktor-faktor yang Mempengaruhi Minat Mahasiswa Dalam Penggunaan APMK. Jurnal Penelitian Hukum Ekonomi Syariah 4(1): 93-103.

Fattah, F. A., M. Indriayu, dan Sunarto. 2018. Pengaruh Literasi Keuangan dan Pengendalian Diri Terhadap Perilaku Konsumtif Siswa SMA Muhammadiyah 1 Karanganyar. Jurnal Pendidikan Bisnis dan Ekonomi (BISE) 4(1): 11-21.

Febrilia, I., S. P. Pratiwi, dan I. Djatikusumo. 2020. Minat Penggunaan Cashless Payment System-Dompet Digital Pada Mahasiswa Di FE UNJ. Jurnal Riset Manajemen Sains Indonesia (JRMSI) 11(1): 1-19. 
Fitriana, N. dan Koentjoro. 2009. Keranjingan Berbelanja pada Wanita Bekerja. Fenomena 7(1): 48-57.

Ghufron, M. N. dan R. R. Suminta. 2017. Hubungan antara kepercayaan epistemologis dengan belajar berbasis regulasi diri. Jurnal Psikologi Insight 1(1): 40-54.

Haryani, I. dan J. Herwanto. 2015. Hubungan Konformitas dan Kontrol Diri Dengan Perilaku Konsumtif Terhadap Produk Kosmetik pada Mahasiswi. Jurnal Psikologi UIN Sultan Syarif Kasim Riau 11(1): 5-11.

King, H. A. 1978. A Nomogram to Assist in Planning Surveys of Small $(\mathrm{N}<2,000)$ Populations. Research Quarterly of the American Alliance for Health, Physical Education and Recreation 49(4): 552-557.

Kumala, I. dan I. Mutia. 2020. Pemanfaatan Aplikasi Dompet Digital Terhadap Transaksi Retail Mahasiswa. Seminar Nasional Riset dan Teknologi: 64-69.

Kumalasari, D. dan Y. H. Soesilo. 2019. Pengaruh Literasi Keuangan, Modernitas Individu, Uang Saku Dan Kontrol Diri Terhadap Perilaku Konsumtif Mahasiswa Prodi S1 Pendidikan Ekonomi Angkatan Tahun 2016 Fakultas Ekonomi Universitas Negeri Malang. Jurnal Pendidikan Ekonomi 12(1): 61-71.

Lawrence, P. A., C. Daniel, dan J. P. Oliver. 2010. Psikologi Kepribadian: Teori dan Penelitian. Kencana Prenada Media Grup. Jakarta.

Lina dan H. F. Rosyid. 1997. Perilaku Konsumtif Berdasar Locus O F Control Pada Remaja Putri Lina. Psikologika 2(4): 5-13.

Liu, F., T. Yilmazer, C. Loibl, dan C. Montalto. 2019. Professional Financial Advice, Self-control and Saving Behavior. International Journal of Consumer Studies 43(1): 23-34.

Nisa, C. L. 2017. Pengaruh Kontrol Diri, Harga Diri, dan Lingkungan Teman Sebaya terhadap Perilaku Konsumtif Belanja Online Mahasiswa Pendidikan Ekonomi Fakultas Ekonomi Universitas
Negeri Semarang Angkatan 2015. Tesis. Universitas Negeri Semarang.

Novak, T. P., D. L. Hoffman, dan Y. F. Yung. 2000. Measuring the Customer Experience in Online Environments: a Structural Modeling Approach. Marketing Science 19(1): 22-42.

Puspita, Y. C. 2019. Analisis Kesesuaian Teknologi Penggunaan Digital Payment Pada Aplikasi Ovo. Jurnal Manajemen Informatika 09(02): 121-128.

Ramadani, L. 2016. Pengaruh Penggunaan Kartu Debit dan Uang Elektronik (EMoney) Terhadap Pengeluaran Konsumsi Mahasiswa. Jurnal Ekonomi dan Ekonomi Studi Pembangunan 8(1): 1-8.

Ramadhan, A. F., A. B. Prasetyo, dan L. Irviana. 2016. Persepsi Mahasiswa Dalam Menggunakan E-money. Jurnal Dinamika Ekonomi \& Bisnis 13(2): 131145.

Ramadhani, R. H. 2019. Pengaruh Literasi Keuangan, Electronic Money, Gaya Hidup, dan Kontrol Diri Terhadap Perilaku Konsumtif Mahasiswa. Skripsi. Univsersitas Sumatera Utara. Medan.

Ramli, R. R. 2020. Pada 2025, Ekonomi Digital RI Bisa Capai Rp 1.995 Triliun. https://money.kompas.com/read/2020/10/19 130000626/pada-2025-ekonomi-digital-ribisa-capai-rp-1.995-triliun. Diakses tanggal 19 Oktober 2020.

Sihombing, R. J. 2017. Keabsahan electronic money di Indonesia. Jurnal Kertha Semaya: Journal Ilmu Hukum 5(2).

Sumanjeet, S. 2009. Emergence of Payment Systems in the Age of Electronic Commerce: the State of Art. Global Journal of International Business Research 2(2).

Strömbäck, C., T Lind, K. Skagerlund, D. Västfjäll, dan G. Tinghög. 2017. Does Self-Control Predict Financial Behavior and Financial Well-being? Journal of Behavioral and Experimental Finance 14: 30-38.

Tripambudi, B. dan E. S. Indrawati. 2018. Hubungan Antara Kontrol Diri Dengan Perilaku Konsumtif Pembelian Gadget 
Pada Mahasiswa Teknik Industri Universitas Diponegoro. Jurnal Empati 7(2): 189-195.

Triyaningsih dan R. Slamet. 2011. Dampak Online Marketing Melalui Facebook Terhadap Perilaku Konsumtif Masyarakat. Jurnal Ekonomi dan Kewirausahaan 11(2): 172-177.
Ulayya, S. dan E. Mujiasih. 2020. Hubungan Antara Self Control Dengan Perilaku Komsumtif Pengguna E-Money Pada Mahasiswa Fakultas Psikologi Universitas Diponegoro: Jurnal Empati 9(4): 271-279. 